\title{
FUTURE ROLE OF AGRICULTURE IN MULTIFUNCTIONAL DEVELOPMENT OF RURAL AREAS
}

\author{
Prof. Henryk Runowski, Ph.D., Prof. Wojciech Zietara, Ph.D.
}

Warsaw University of Life Sciences

\begin{abstract}
In the paper the changes in agriculture in terms of falling share of agriculture in gross domestic product and decrease in the share of persons employed in agriculture in total employment in Poland and selected countries are discussed. The main driver of these changes is a faster pace of development of non-agricultural activities and continually deteriorating relations between the costs of production factors and prices of agricultural products. The rate of growth in labor costs and prices of the means of production for agriculture is much faster than the rate of increase in prices of agricultural products. This causes the decline in profitability of agricultural production which increases the size of farms. The pace is dependent on the level of economic development of the country. The study also identified trends in the structure of farms, functions and systems of agriculture in the generational perspective. The polarization of the farms will deepen. A strong group of commodity farms and a group of so-called self - subsistence social farms will emerge. Agriculture in Poland will have a dual nature. In addition to the production function and social services agriculture will expand the scope of service functions for the environment and society.
\end{abstract}

Key words: ?????

\section{Introduction}

Agriculture is one of the key sectors of national economy in determining the level of nutrition of the population and food security of the country. Its role and functions are changing along with economic development and social expectations. The shape of changes in farming conditions is determined by economic, legal, environmental, technological, international, institutional, demographic and socio-cultural conditions. Each of these areas, both individually and in conjunction with the other, sets the direction and the logic of transformation in agriculture.

This article aims to attempt to assess the current state of Polish agriculture and to delimit the anticipated changes, in response to the challenges arising from the principles of multifunctionality and sustainable development. The paper will discuss the following issues: a place of agriculture in national economy, the economic drivers of change in agriculture, trends of changes in the level and the relationship between factors of production, trends of organizational changes in agriculture and its functions in the coming years 2020-2025.

\section{Place of agriculture in national economy}

The basic indicators for assessing the significance of agriculture include: the share of agriculture in gross domestic

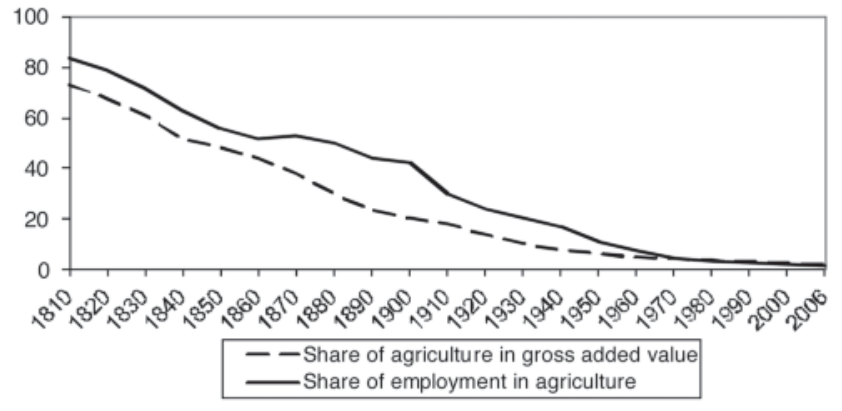

Figure 1. The trend of changes in the share of agriculture in the structure of manufacturing gross domestic product and total employment in the U.S. Source: Tomczak F.: Od rolnictwa do agrobiznesu. Wyd. SGH. Warszawa 2004. [From Agriculture to Agro-business]

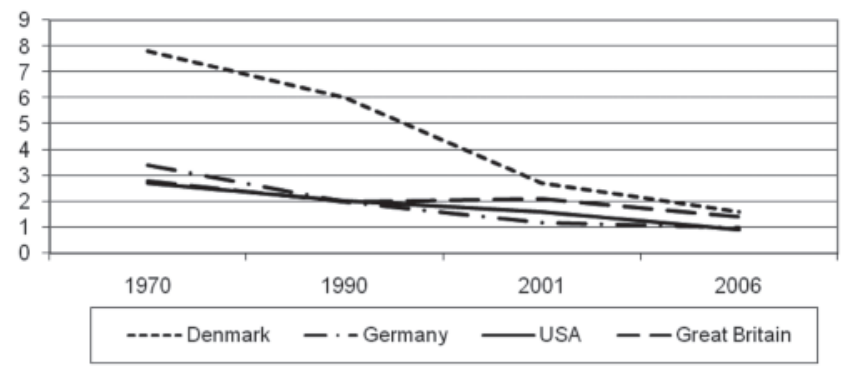

Figure 2. The trend of changes in the share of agriculture in gross value added structure in selected countries

Source: Rocznik Statystyczny Rolnictwa i Obszarów Wiejskich. GUS. Warszawa 2006. Roczniki Statystyczne GUS. Warszawa 1996-2007. [Statistical Yearbook of Agriculture and Rural Areas] 
product or value added and share of agricultural employment in total employment. Model example for changes in agriculture involves the United States (Fig. 1). In 1810-2006 the share of employed in agriculture and the share of agriculture in GDP fell from around $84 \%$ in 1810 and $73 \%$ to about $1 \%$ in 2006. Similar trends have occurred in European countries (eg Denmark, Germany, United Kingdom). The trend in values of the share of agriculture in gross added value in these countries in 1970-2006 are shown in Figure 2.

Figure 2 shows that in 1970-2006 in the analyzed countries, the agricultural gross value added showed a downward trend. The pace of decline in Britain and Germany was similar to those in the U.S. In 2006, the share of agriculture in gross value added in these countries was around $1 \%$. By contrast, in Denmark, this share was higher and in 2006 it was $1.6 \%$. Similar trends occurred in the analyzed countries in terms of employment (Figure 3).

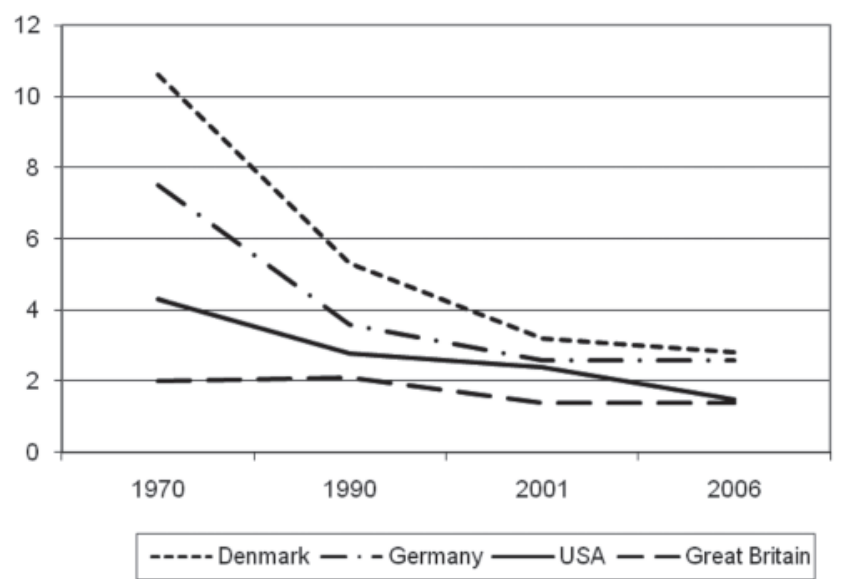

Figure 3. The trend of changes in the share of agriculture in the structure of employment in selected countries

Source: Rocznik Statystyczny Rolnictwa i Obszarów Wiejskich. GUS. Warszawa 2006. Roczniki Statystyczne GUS. Warszawa 1996-2007. [Statistical Yearbook of Agriculture and Rural Areas]

Figure 3 shows that the level and rate of decline in agricultural employment in the UK and the U.S. were similar. In 2006, the share of agricultural employment in total employment was $1.4 \%$. In Denmark and Germany, this share was higher and amounted to respectively $2.8 \%$ and $2.6 \%$.

Figure 4 presents the trends of the share of agriculture in employment and gross value added in Poland in 1950-2006. In this period the share of workers employed in agriculture declined from $50 \%$ in 1950 to $16.2 \%$ in 2006 . The reduction was significant, but still the share of employed in Polish agriculture compared to previously analyzed developed countries of Western Europe was very high. Strong downward trends occurred in the share of agriculture in gross value added. In 1950 this share was $30 \%$ while in 2006 only $3.7 \%$. The high share of agriculture in gross value added and total employment in Poland in 1950 was typical of a agriculture oriented country. Present trends in this area in Poland are similar to those in Western Europe, however, shifted in time by about 50 years. A similar share of agricultural employment which now occurs in Poland occurred in those countries in the postwar period of 1950 to 1960.

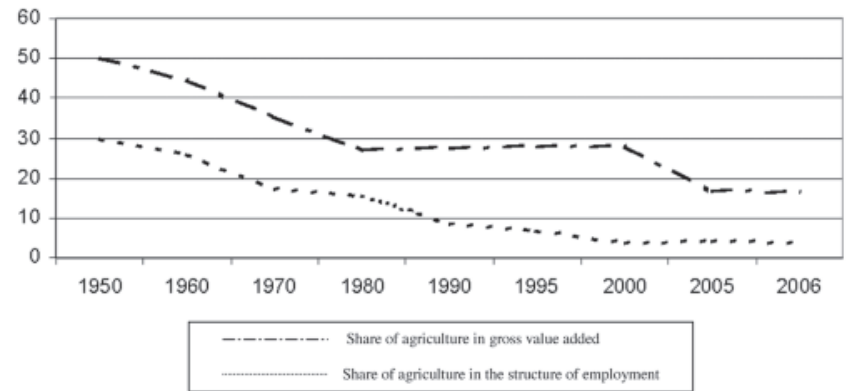

Figure 4. The trend of changes in the share of agriculture in the structure of employment and gross value added in Poland

Source: Rocznik Statystyczny Rolnictwa i Obszarów Wiejskich. GUS. Warszawa 2006. Roczniki Statystyczne GUS. Warszawa 1996-2007. [Statistical Yearbook of Agriculture and Rural Areas]

Despite the decline of the formal share of agriculture in gross value added it is a very important part of the economy and, above all, is the basis for the functioning and development of agricultural processing sector. Furthermore, it is the predominant element in the rural economy [Wilkin 2008].

\section{Economic factors of changes in the Polish agriculture}

The transformation of agriculture in recent decades in Poland was influenced by changes in the prices of production factors and prices of agricultural products (Figure 5). The highest growth rate in this period involved labor costs showing particularly high growth in non-agricultural branches and slightly lower prices of goods purchased by farmers. However, the increase was much lower in prices of agricultural products sold by farmers. Indicator of price

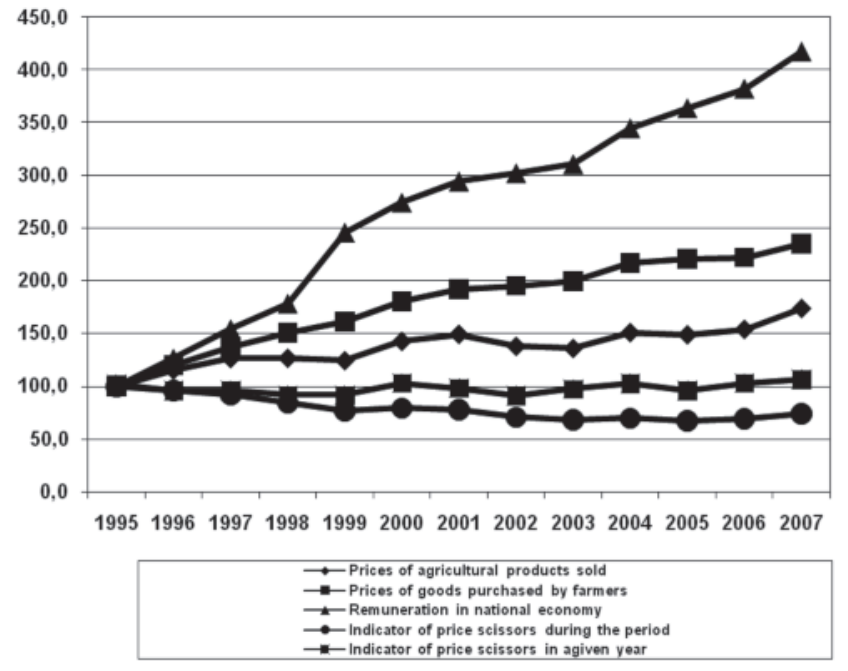

Figure 5. Changes in the prices of production factors and agricultural products in Poland in 1995-2007

Source: Analiza produkcyjno-ekonomicznej sytuacji rolnictwa i gospodarki żywnościowej w latach 1996, 2000, 2005, 2007, 2008. IERiGŻ - PIB. Warszawa. [Analysis of Production-Economic Condition of Agriculture and Food Economy in 1996, 2000, 2005, 2007, 2008.] 
scissors in each year averaged to about $100 \%$. In 1998-2000 and 2002-2003, it was below $100 \%$ while in other years it exceeded $100 \%$. In 2007, the exceptionally favorable to agriculture, it amounted to $106.5 \%$. Indicator of price scissors in the entire analyzed period was definitely detrimental to agriculture and in 2007 was about $75 \%$ taking $1995=100 \%$. This means that labor costs and prices of agricultural production grew much faster $(25 \%)$ than the sale prices of agricultural products.ü

Present trends are characteristic of all market economy countries, with the timeless nature of regularity. They cause fall in unit profitability of agricultural production. Farmers wishing to achieve the income from their farms at least at the parity level (similar to the salaries of workers in nonagricultural departments) must increase the scale of production and implement the technological progress in its broad sense. This objective can be achieved mainly by increasing the size of farms.

In 1990, the Polish farmer's income at the parity level could be obtained from a farm of 10 ha of utilized agricultural area (UAA). In the next two years, the area had risen to over 15 ha. In 1995-2001 parity farm size ranged from 20 to 50 ha [Ziętara 2000, 2003]. The results of the farm accountancy in FADN system indicate that the minimum area of a farm parity in 2005 was included in the range of 20-30 ha, depending on the region. [AgricultureFADN in 2008]. The results given correspond to the results of W. Józwiak, who shows that in 2004-2006 the volume of farm parity was about 35 ha, which corresponded to the economic size of holdings range from 16 to $40 \mathrm{ESU}^{1}$ [Józwiak, 2008]. Generally it can be concluded that the area of farm parity is still growing. In the next few years it is likely to reach a size of 50 ha of UAA.

\section{Changes in production factors}

Evaluation of the basic resource of the Polish agriculture, which is the land, was made by reference to selected countries in Western Europe. It concerns changes in the utilized agricultural area in total and per one inhabitant in 1990-2006. In all countries there is a decline in the UAA in this period, in average by $5 \%$. In Poland, the decrease in surface area was considerably higher and amounted to $15 \%$. UAA in this period declined from 18.7 million hectares to 15.9 million ha. Surface reduction was mainly caused by the exclusion from agricultural use of low quality land [Central Statistical Office (GUS) Statistical Yearbooks 1966-2007].

In terms of UAA per 1 citizen in 2005, Poland had a similar potential as Denmark and France (about 0.5 hectares per capita), but definitely higher than the United Kingdom and Germany, where these rates were respectively 0.28 and 0 21 ha [CSO Statistical Yearbooks from 1966 to 2007].

The decrease of farmland per 1 inhabitant is a constant trend in all countries.

Polish agriculture is characterized by an unfavorable structure of the area. This is proved by the low average farm size, which in 2005 was only 6.4 ha [CSO Statistical Yearbooks from 1966 to 2007]. In the countries compared, the average household size was 6 (France, Germany) to 9 times higher (Denmark, United Kingdom). Other indicators characterizing the structure of the farm area are: the share of holdings of 5 ha and over 50 ha. The relevant data have been presented in Table 1. In Poland, in 2005 the share of farms with an area of 5 ha was $57.4 \%$ while in Denmark $4 \%$. In Germany and France it is contained in the range of 23-28\% while the UK it was $37 \%$. Despite a significant share of small farms in the UK, over $65 \%$ of arable land is in use of farms of

Table 1. Number of farms of the area exceeding 1 ha in Poland in the period 2002-2007 and in selected countries in 2005 (in thousands).

\begin{tabular}{|c|c|c|c|c|c|}
\hline \multirow{2}{*}{ Year } & \multirow{2}{*}{ Total } & \multicolumn{4}{|c|}{ Farm size clusters } \\
\hline & & $1-5$ & $5-20$ & $20-50$ & $>\mathbf{5 0}$ \\
\hline 2002 & $\begin{array}{c}\text { Number } 1,951.7 \\
\% 100 \\
\end{array}$ & $\begin{array}{c}1,146.3 \\
58.7 \\
\end{array}$ & $\begin{array}{c}692.8 \\
35.5 \\
\end{array}$ & $\begin{array}{c}95.5 \\
4.9 \\
\end{array}$ & $\begin{array}{c}17.1 \\
0.9 \\
\end{array}$ \\
\hline 2005 & $\begin{array}{c}\text { Number } 1,782.3 \\
\% 100.0\end{array}$ & $\begin{array}{c}1,031.9 \\
57.9\end{array}$ & $\begin{array}{c}632.9 \\
35.5\end{array}$ & $\begin{array}{c}98.7 \\
5.5\end{array}$ & $\begin{array}{c}18.8 \\
1.1\end{array}$ \\
\hline 2007 & $\begin{array}{c}\text { Number } 1,804.1 \\
\% 100.0 \\
\end{array}$ & $\begin{array}{c}1,036.5 \\
57.4 \\
\end{array}$ & $\begin{array}{c}643.8 \\
35.7 \\
\end{array}$ & $\begin{array}{c}102.3 \\
5.7 \\
\end{array}$ & $\begin{array}{c}21.5 \\
1.2 \\
\end{array}$ \\
\hline \multicolumn{6}{|c|}{ Selected countries in 2005} \\
\hline Denmark & $\begin{array}{c}\text { Number } 49.0 \\
\% 100 \\
\end{array}$ & $\begin{array}{l}2.0 \\
4.1 \\
\end{array}$ & $\begin{array}{l}19.0 \\
38.8 \\
\end{array}$ & $\begin{array}{l}12.0 \\
24.4\end{array}$ & $\begin{array}{l}16.0 \\
32.7 \\
\end{array}$ \\
\hline France & $\begin{array}{c}\text { Number } 567.0 \\
\% 100\end{array}$ & $\begin{array}{c}148.0 \\
26.1\end{array}$ & $\begin{array}{c}110.0 \\
19.4\end{array}$ & $\begin{array}{c}109.0 \\
19.2\end{array}$ & $\begin{array}{c}200.0 \\
35.3 \\
\end{array}$ \\
\hline Germany & $\begin{array}{c}\text { Number } 390.0 \\
\% 100 \\
\end{array}$ & $\begin{array}{l}88.0 \\
22.6 \\
\end{array}$ & $\begin{array}{c}129.0 \\
33.1 \\
\end{array}$ & $\begin{array}{l}88.0 \\
22.6 \\
\end{array}$ & $\begin{array}{l}85.0 \\
21.8 \\
\end{array}$ \\
\hline Great Britain & $\begin{array}{c}\text { Number } 287.0 \\
\% 100\end{array}$ & $\begin{array}{c}107.0 \\
37.3\end{array}$ & $\begin{array}{l}59.0 \\
20.5\end{array}$ & $\begin{array}{l}47.0 \\
16.4\end{array}$ & $\begin{array}{l}74.0 \\
25.8\end{array}$ \\
\hline
\end{tabular}

Source: Charakterystyka gospodarstw rolnych w 2005 r. GUS. Warszawa 2006. Charakterystyka gospodarstw rolnych w 2007 r. GUS. Warszawa 2008 Rocznik Statystyczny Rolnictwa i Obszarów Wiejskich. GUS. Warszawa 2006. Systematyka i charakterystyka gospodarstw rolnych. Powszechny Spis Rolny 2002. GUS. Warszawa 2003. [Characteristic Features of Agricultural Farms. Statistical Yearbook of Agriculture and Rural Areas. Systematics and Characteristics of Agricultural Farms: Public Agricultural Inventory]

${ }^{1}$ ESU (European Size Unit) is a measure of economic size of farm. One ESU corresponds to the equivalent of the EURO 1200 standard gross margin. 
Table 2. Forecasted changes in the structure of farms in the period 2007-2030

\begin{tabular}{|c|c|c|c|c|c|c|}
\hline \multirow{3}{*}{ Specification } & \multicolumn{6}{|c|}{ Farm holdings (thousands) } \\
\hline & \multicolumn{2}{|c|}{2007} & \multicolumn{2}{|c|}{2020} & \multicolumn{2}{|c|}{2030} \\
\hline & Number & $\%$ & Number & $\%$ & Number & $\%$ \\
\hline $\begin{array}{l}\text { Over } 1 \text { ha } \\
\text { in this (ha): }\end{array}$ & 1804.1 & 100.0 & 1468.5 & 100.0 & 1258.5 & 100.0 \\
\hline $1-5$ & 1036.5 & 57.5 & 787.0 & 53.6 & 591.5 & 47.0 \\
\hline $5-20$ & 643.8 & 36.5 & 523.0 & 35.6 & 447.5 & 35.5 \\
\hline $20-50$ & 102.3 & 5.7 & 120.0 & 8.2 & 146.2 & 11.6 \\
\hline $50-100$ & 15.6 & 0.9 & 29.0 & 1.9 & 56.0 & 4.5 \\
\hline $100-300$ & 4.9 & 0.3 & 8.8 & 0.6 & 16.2 & 1.3 \\
\hline $300-500$ & 0.6 & 0.0 & 0.4 & 0.1 & 0.6 & 0.1 \\
\hline $500-000$ & 0.3 & 0.0 & 0.2 & 0.0 & 0.3 & 0.0 \\
\hline 1000 and more & 0.1 & 0.0 & 0.1 & 0.0 & 0.2 & 0.0 \\
\hline $\begin{array}{l}\text { Average area of } \\
\text { individual farms } \\
\text { exceeding } 1 \text { ha }\end{array}$ & \multicolumn{2}{|c|}{7.8} & \multicolumn{2}{|c|}{9.2} & \multicolumn{2}{|c|}{10.7} \\
\hline Other private forms & \multicolumn{2}{|c|}{3.0} & \multicolumn{2}{|r|}{3.0} & \multicolumn{2}{|r|}{3.0} \\
\hline $\begin{array}{l}\text { In this cooperative } \\
\text { farms }\end{array}$ & \multicolumn{2}{|c|}{0.9} & \multicolumn{2}{|r|}{0.7} & \multicolumn{2}{|r|}{0.5} \\
\hline State owned sector & \multicolumn{2}{|c|}{1.0} & \multicolumn{2}{|r|}{0.7} & \multicolumn{2}{|r|}{0.5} \\
\hline Total farms over 1 ha & \multicolumn{2}{|c|}{1808.1} & \multicolumn{2}{|r|}{1472.2} & \multicolumn{2}{|r|}{1262.5} \\
\hline
\end{tabular}

Source: Charakterystyka gospodarstw rolnych w 2007 r. GUS. Warszawa 2008 [Characteristics of Agricultural Farms. Yearbook]

over 100 ha [Steffen 2004]. For this reason, the average size of farms is high here, i.e. approximately 60 hectares. The share of farms with an area exceeding 50 ha in Poland is extremely low and in 2005 it was $1.1 \%$. And the corresponding rate in the countries surveyed was in the range of $21 \%$ (Germany) to $35 \%$ (Denmark and France). A highly negative picture of the area structure of farms in Poland as compared to European countries of the highest level of agriculture is mitigated by the analysis of the figures shown in Table 1 , where are the structure of farms and the change trends in 2002-2007 are given.

The figures shown in Table 1 indicate positive trends. In 2002-2007 the share of farms of the area of 20-50 ha and over 50 ha has increased respectively by $0.8 \%$ and $4.4 \%$, while a small decrease in the number and share of holdings in the range of $1-5$ ha might be observed. These processes should be assessed positively, although the pace of these changes is slow. However, as concluded by Majewski [2008, p.44] "in the near future stronger demand for agricultural land... and further transfers of land enlarging size of Polish farms and deepening an existing polarization of the [Characteristics of Agricultural Farms. Yearbook] farm structure can be forseen". Similar processes occurred in German agriculture [Reisch 2004].

The forecast for the next 20-25 years leads to a conclusion that there will be further positive changes in the structure of farms. The relevant numbers have been presented in tables 2 and 3. Still, this structure differs from the currently occurring in the compared countries.

Table 4 contains numbers characteristic for labor resources in Poland and the studied countries in 1996-2006.

There is a fundamental difference between the studied countries and Poland in the number of workers and the share of employed in agriculture in relation to the overall number of employees. A characteristic feature in all analyzed countries was a decline in the number of people employed in agriculture. It was included in the range

Table 3. Forecasted changes in the utilization of the agricultural area in farm size clusters in the period 2007-2030 (in thousand ha)

\begin{tabular}{|c|c|c|c|c|c|c|}
\hline \multirow{3}{*}{ Specification } & \multicolumn{6}{|c|}{ Utilized Agricultural Area } \\
\hline & \multicolumn{2}{|c|}{2007} & \multicolumn{2}{|c|}{2020} & \multicolumn{2}{|c|}{2030} \\
\hline & ha & $\%$ & ha & $\%$ & ha & $\%$ \\
\hline $\begin{array}{l}\text { Over } 1 \text { ha } \\
\text { in this (ha): }\end{array}$ & 14087.3 & 100.0 & 13537.7 & 100.0 & 13432.6 & 100.0 \\
\hline $1-5$ & 2603.3 & 18.5 & 2217.3 & 16.4 & 1964.5 & 14.6 \\
\hline $5-20$ & 6189.1 & 44.0 & 5057.1 & 37.4 & 4103.5 & 30.5 \\
\hline $20-50$ & 2955.5 & 21.0 & 3238.9 & 23.9 & 3549.5 & 26.5 \\
\hline $50-100$ & 1044.2 & 7.4 & 1524.7 & 11.3 & 2064.0 & 15.4 \\
\hline $100-300$ & 757.1 & 5.3 & 909.8 & 6.7 & 1093.3 & 8.1 \\
\hline $300-500$ & 228.6 & 1.6 & 252.4 & 1.9 & 277.6 & 2.1 \\
\hline $500-1000$ & 208.9 & 1.5 & 237.5 & 1.7 & 279.0 & 2.0 \\
\hline 1000 and more & 100.6 & 0.7 & 100.0 & 0.7 & 110.0 & 0.8 \\
\hline Other private farms & \multicolumn{2}{|c|}{1189.3} & \multicolumn{2}{|c|}{1200.0} & \multicolumn{2}{|c|}{1200.0} \\
\hline State owned sector & \multicolumn{2}{|c|}{569.6} & \multicolumn{2}{|c|}{315.6} & \multicolumn{2}{|c|}{150.0} \\
\hline Total area over 1 ha & \multicolumn{2}{|c|}{15846.2} & \multicolumn{2}{|c|}{15053.3} & \multicolumn{2}{|c|}{14782.4} \\
\hline
\end{tabular}

Source: Charakterystyka gospodarstw rolnych w 2007 r. GUS. Warszawa 2008 Rocznik, own study

of $9 \%$ (France) to $31 \%$ (Poland). High decline in employment in Poland in this period was mainly the result of changes in the employees' in agriculture counting methodology in the Agricultural Census in 2002 [Systematics, 2003] $]^{2}$. Regardless of the change in the methodology of workload counting, the reduction of employment in the Polish agriculture was influenced by the increasing levels of mechanization, and changes in the structure of production. Increase in the proportion of cereals in the crop

\footnotetext{
2 In previous years, resources in agriculture were described by the number of economically-active employees, while in 2002 and next years, the so-called fulltime employees were counted, taking into account the working time at a farm
} 
Table 4. Employment in agriculture in Poland and in selected countries of the European Union, in the period 1996-2006 (in thousand and 100 per ha of UAA)

\begin{tabular}{|c|c|c|c|c|c|c|c|c|c|c|}
\hline \multirow{2}{*}{ Year } & \multicolumn{2}{|r|}{ Denmark } & \multicolumn{2}{|r|}{ France } & \multicolumn{2}{|r|}{ Germany } & \multicolumn{2}{|c|}{ Great Britain } & \multicolumn{2}{|r|}{ Poland } \\
\hline & Total & Per 100 ha UAA & Total & Per 100 ha UAA & Total & Per 100 ha UAA & Total & Per 100 ha UAA & Total & Per 100 ha UAA \\
\hline 1996 & 103 & 3.7 & 1048 & 3.5 & 1076 & 6.3 & 512 & 2.9 & 3310 & 17.7 \\
\hline 2001 & 89.9 & 3.3 & 971 & 3.2 & 942 & 5.5 & 391 & 2.3 & 2720 & 15.3 \\
\hline 2004 & 84.6 & 3.3 & 994 & 3.3 & 832 & 4.9 & 356 & 2.1 & 2484 & 15.6 \\
\hline 2006 & 79.4 & 2.9 & 953 & - & 843 & 4.9 & 384 & - & 2300 & 14.4 \\
\hline
\end{tabular}

Source: Rocznik Statystyczny Rolnictwa i Obszarów Wiejskich. GUS. Warszawa 2006. Roczniki Statystyczne GUS.. Warszawa 1996-2007. [Statistical Yearbook of Agriculture and Rural Areas]

structure, from $60 \%$ in 1990 to $73.8 \%$ in 2007 [Characteristics, 2007], and a reduction in livestock density from 58 LU per 100 ha UAA in 1994 to 49 LU per 100 ha UAA in 2007 [Characteristics, 2007].

There were also significant differences between compared countries and Poland in the share of agricultural workers in general employment. In the countries under comparison, this share was in the range of $1.4 \%$ (Great Britain) to $4 \%$ (France). In Poland this indicator was $22.1 \%$ in 1996 and $16.2 \%$ in 2006. Very significant differences can also be found in labor resources per 100 ha UAA. In 2006 in the countries under comparison, the labor force ranged from 2 (United Kingdom) to 5 (Germany) persons per 100 ha UAA. In Poland, the rate was 14.4 persons on average. This is on the one hand, a strength of Polish agriculture, on the other hand it is a barrier preventing the increase in the agricultural income. The figures given in Table 5, which refer to households with an area of over 1 ha UAA support this statement.

Table 5. Labor force in farm size clusters in the years 2005 and 2007 (thousand of FWU)

\begin{tabular}{|l|l|r|r|r|r|r|r|}
\hline \multicolumn{2}{|l|}{ Specification } & \multicolumn{1}{c|}{ Total } & $\mathbf{1 - 5}$ ha & $\mathbf{5 - 1 0}$ ha & $\mathbf{1 0 - 2 0}$ ha & $\mathbf{2 0 - 5 0}$ ha & $\mathbf{> 5 0}$ ha \\
\hline \multirow{3}{*}{2005} & Total & 2027.1 & 783.4 & 551.8 & 433.3 & 207.2 & 51.4 \\
\cline { 2 - 8 } & Per 100 ha UAA & 14.9 & 30.9 & 20.0 & 12.9 & 7.3 & 2.4 \\
\cline { 2 - 8 } & \% labor force & 95.3 & 97.5 & 96.4 & 95.3 & 91.4 & 67.1 \\
\hline \multirow{2}{*}{2007} & Total & 2047.8 & 796.8 & 556.9 & 426.2 & 209.3 & 58.6 \\
\cline { 2 - 8 } & Per 100 ha UAA & 14.5 & 30.6 & 20.2 & 12.7 & 7.4 & 2.7 \\
\cline { 2 - 8 } & \% labor force & 95.1 & 97.5 & 96.0 & 94.8 & 92.0 & 67.4 \\
\hline
\end{tabular}

Source: Charakterystyka gospodarstw rolnych w 2005 r. GUS. Warszawa 2006. Charakterystyka gospodarstw rolnych w 2007 r. GUS. Warszawa 2008. [Characteristics of Agricultural Farms]
About $25 \%$ of farmers had primary complete and incomplete education. In the farms of over 100 ha share of farmers with higher education was about $21 \%$ [Ziętara, 2009]. It is clear that the level of education of Polish farmers is insufficient as compared to the needs.

The average age of employed in agriculture in 2007 was about 45 years. There is a significant correlation between the area of farms and the age of employees. With the increase in the average age the area decreases.

Characteristic for the agriculture of Poland is a relatively low production intensity level - as an indicator mineral fertilizers in $\mathrm{kg} \mathrm{NPK/ha} \mathrm{can} \mathrm{be} \mathrm{used} \mathrm{(Table} \mathrm{6).} \mathrm{This} \mathrm{is} \mathrm{one} \mathrm{of}$ the reasons of lower productivity of land. The average milk yield per cow in the Polish agriculture is also lower compared to other European countries with intensive agriculture.

The above data indicate that the direction of changes in Polish agriculture is similar to that of the comparable Western European countries, but the advancement of these processes is weaker. There is a characteristic time lag. There are many reasons for this. One can mention among them the issues of demographic differences, the level of economic development, and inhibition of natural transformation in agriculture in the first four decades of the postwar period. Under the present conditions, there is a need for new perspectives on the
In the smaller farms the labor resources are over two times higher than the country average in comparable countries. The labor force on farms with the area exceeding 50 ha UAA is only similar to the labor force in the compared countries.

The labor potential in agriculture depends largely on quality of labor force, which can be characterized by the education and age of people working in agriculture. In 2007, only $6.6 \%$ of farmers held a university degree. The share of farmers with secondary and vocational education was respectively $29.3 \%$ and $39.2 \%$.
Table 6. Use of mineral fertilizers in $\mathrm{kg} \mathrm{NPK/ha} \mathrm{and} \mathrm{yields} \mathrm{from} \mathrm{selected} \mathrm{production} \mathrm{activities}$

\begin{tabular}{|l|l|c|c|c|c|c|}
\hline Year & & Denmark & France & Germany & Great Britain & Poland \\
\hline 1995/1996 (kg NPK/ha) & & 160.7 & 163.5 & 162.7 & 126.1 & 84.5 \\
\hline 2002/2003 (kg NPK/ha) & & 111.3 & 134.3 & 152.9 & 106.1 & 93.6 \\
\hline \multirow{3}{*}{ Cereals (dt/ha) } & 1995 & 62.1 & 64.6 & 61.1 & 68.7 & 30.2 \\
\cline { 2 - 7 } & 2000 & 62.0 & 72.4 & 64.5 & 71.6 & 25.3 \\
\cline { 2 - 7 } & 2005 & 62.0 & 69.8 & 67.3 & 72.0 & 32.3 \\
\hline \multirow{3}{*}{ Sugar beet (dt/ha) } & 1995 & 462 & 668 & 497 & 430 & 346 \\
\cline { 2 - 7 } & 2000 & 565 & 759 & 617 & 525 & 394 \\
\cline { 2 - 7 } & 2005 & 576 & 573 & 602 & 574 & 416 \\
\hline \multirow{3}{*}{ Milk litters/cow/year } & 1995 & 6657 & 5517 & 5424 & 5703 & 3231 \\
\cline { 2 - 7 } & 2000 & 7421 & 5948 & 6122 & 6155 & 3778 \\
\cline { 2 - 7 } & 2005 & 8156 & 6548 & 6439 & 6975 & 4271 \\
\hline
\end{tabular}

Source: Rocznik Statystyczny Rolnictwa i Obszarów Wiejskich. GUS. Warszawa 2006. [Statistical Yearbook of Agriculture and Rural Areas] 
role and functions of agriculture in the context of multifunctionality and sustainability of its development and designation of the directions of changes.

\section{Directions of changes in agriculture in view of generational perspective}

Directions of changes in agriculture will be discussed in several areas. These include the strategies of agricultural functioning, use of technological advances, models of agriculture, the functions of agriculture and agricultural production systems.

Strategies of agricultural functioning

In order to survive, Polish agriculture must be equipped with special, durable and defendable types of competitive advantage. Theoretically, these advantages may come from three sources:

- Land and Latour productivity increase,,

- specific skills, which allow to provide the market with distinctive products,

- taking additional non-agricultural activities.

The primary means of achieving competitive advantage is to improve the efficiency of production. Figure 6 shows the key ways to improve efficiency in agriculture

These include improving the economic efficiency and the search by farmers of alternative sources of income [Runowski, 2004].

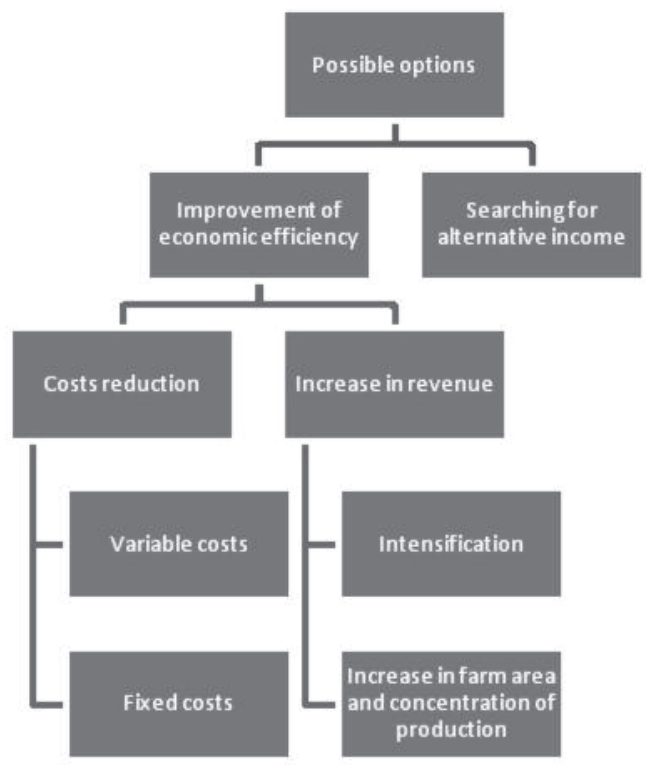

Figure 6. Ways of efficiency improvement in agriculture

Source: Runowski H.: Kierunki rozwoju przedsiębiorstw rolniczych w Polsce. Postępy Nauk Rolniczych, nr 3. Warszawa 2004. [Directions of Development of the Agricultural Holdings in Poland. Advancement in Agricultural Sciences.]

\section{The importance of technical progress in the adjustment process of agriculture}

In view of the ever-growing challenges of efficiency in agriculture, the broadly defined technical progress becomes particularly important, as it provides improved efficiency of outlays. Thanks to technological advances, the same quantity of financial outlays causes higher level of production. In the Polish agriculture it is necessary to more widely use various kinds of progress, in this mainly the biological, which is a kind of substitute for substantial investment, and leads to a reduction of costs in agricultural production [Runowski 1997].

\section{Evolution of functions of agriculture}

In many situations, the chances for increase of farm income from typically agricultural activities are limited. This forces the need to seek other opportunities to improve the economic situation of farming families. Such possibilities result from different instruments of the EU Common Agricultural Policy, or national policies that promote forms of agricultural management more friendly to the environment and animals.

It means that agriculture can and must extend the scope of its existing functions in accordance with the proposals set out in Figure 7.

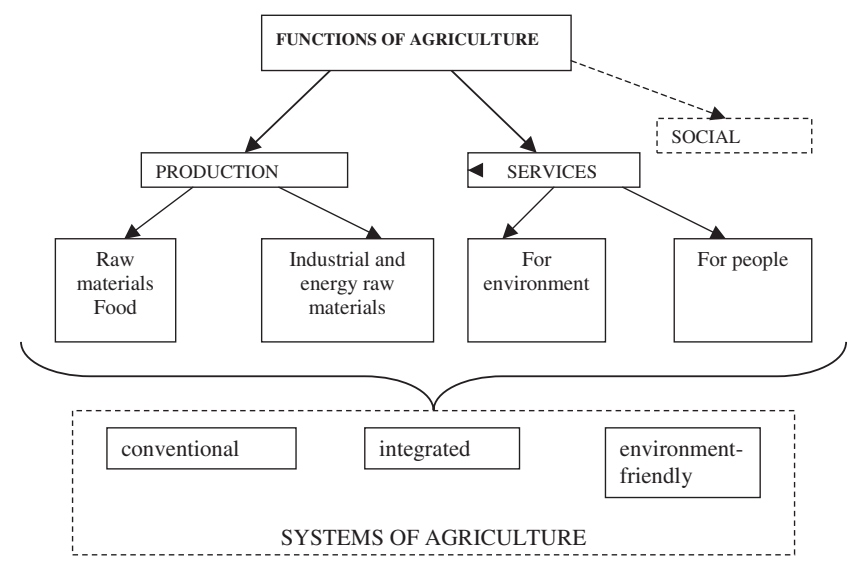

Figure 7. Basic functions of agriculture

Source: Runowski H.: Kierunki rozwoju przedsiębiorstw rolniczych w Polsce. Postępy Nauk Rolniczych, nr 3. Warszawa 2004. [Directions of Development of the Agricultural Holdings in Poland. Advancement in Agricultural Sciences.]

In addition to the production function, there must appear functions of a service nature for the environment, its biodiversity, animal welfare or conservation of traditional plant and animal species as well as services for the public, including, inter alia, tourism [Runowski 2009]. Finally, the social function should be mentioned. It concerns the small farms that produce food products exclusively or in significant advantages for their own needs. Evolution of the proportions of the three functions: manufacturing, service and social services are presented in Figure 8.

In addition to the existing feature of the production, the feature of agriculture services for the population and the environment will gain increasing importance. Along with them there will be the social function. This means that future agriculture increasingly will fit into the concept of multifunctionality and development in 
rural areas. A typical Polish village in the next few years will continue, however, to be mainly associated with agriculture, but its economic and social landscape will include different, new production and service activities, which are additional sources of income of the farming population.

TODAY

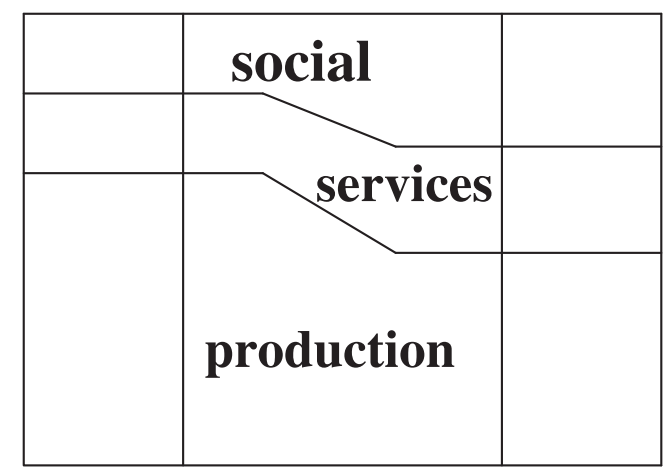

Figure 8. Changes in the proportion of functions of agriculture in time Source: Own study

\section{Model of the Polish Agriculture}

Analyzing trends in changes, an attempt to determine the pattern of development of Polish agriculture was made. This model is affected by many factors, mostly related to globalization and European integration. Despite the external factors, the enormous role is played by permanent concentration processes, which occur in the immediate vicinity of agriculture, mainly in the businesses of trade and agricultural processing. These processes directly lead to an increase in the scale of production on agricultural farms and holdings. They also enforce the increase in quality of agricultural products. Only the production units in agriculture of the adequate scale will be able to meet the demands of trade and agricultural processing [Ziętara, 2009]

In our climate zone two extreme organizational models of agriculture can be differentiated (table 7):

- the so-called model of plantation agriculture, characteristic for certain states in the USA, South America and Australia,

- the Western European model of agriculture.

Table 7. Agriculture models in the world

\begin{tabular}{|c|c|c|}
\hline Specification & PLANTATION & WEST EUROPE \\
\hline Regions & $\begin{array}{c}\text { USA, South America, } \\
\text { Australia }\end{array}$ & $\begin{array}{l}\text { Western European } \\
\text { countries }\end{array}$ \\
\hline - Features & $\begin{array}{l}\text { - Disappearance of traditional } \\
\text { farms, mostly family businesses, } \\
\text { - Specialized companies in the } \\
\text { form of corporations, } \\
\text { - Livestock production conducted } \\
\text { by industrial methods, } \\
\text { - Connections with agricultural } \\
\text { processing companies, } \\
\text { - Increased burden on the } \\
\text { environment, } \\
\text { - Low production costs. }\end{array}$ & $\begin{array}{l}\text {-The dominance of family } \\
\text { farms, } \\
\text { - Smaller scale of } \\
\text { production, } \\
\text { - Relationships in the form } \\
\text { of horizontal integration, } \\
\text { - Reduced load on the } \\
\text { environment, } \\
\text { - Higher production costs }\end{array}$ \\
\hline
\end{tabular}

Source: Own study
The plantation model is characterized by the disappearance of traditionally understood family farms. Production of agricultural raw materials is provided by specialized companies having the legal form of equity companies engaged in activities over large spaces. These companies are mostly related by means of capital to the agricultural processing enterprises. Livestock production is carried out industrially on a large scale. This system results in the production of the most significant environmental burden.

Western European model of agriculture is based to a large degree on family farms of smaller production scale, in which more attention is paid to the quality of the environment. There are links between farms in the form of horizontal integration, which increases their bargaining power in relation to the agricultural trade businesses and the relationships of vertical integration nature allowing the farmers to participate in the benefits achieved by the trade and agriculture processing companies.

Taking into account the conditions of our country, one can most likely assume that model of agriculture based on the Western family farms will dominate in the near future (Table 8).

In addition to this form of legal and organizational forms there will also be other legal forms, such as a limited liability company, particularly in the Northern and Western Poland, where until 1990 were dominating state farms. Other forms of companies will also occur in the future, but will not play a decisive role.

Generalizing the previous considerations it can be stated that in Poland in the near, foreseeable future the dual model of agriculture will dominate, which will cover two groups of farms: i.e. the so called social and commodity farms.

Table 8. Models of agriculture for Poland

\begin{tabular}{|c|c|}
\hline $\begin{array}{c}\text { Domination of the } \\
\text { Western European model }\end{array}$ & Place for large enterprises \\
\hline $\begin{array}{c}\text { Increased role of vertical and horizontal } \\
\text { relationships for the farms } \\
\text { Polarization: } \\
\text { - Significant share of the number of } \\
\text { small farms (to } 5 \text { ha) } \\
\text { - Reduced number of medium farms } \\
\text { (5-20 ha) } \\
\text { Increased number of large farms } \\
(>20 \text { ha) }\end{array}$ & $\begin{array}{c}\text { Increased role of vertical } \\
\text { relationships } \\
\text { Possible splitting of large } \\
\text { holdings into smaller companies } \\
\text { - a reaction to the agricultural } \\
\text { policy objectives }\end{array}$ \\
\hline \multicolumn{2}{|c|}{$\begin{array}{l}\text { The growing importance of production to reduce the burden on the } \\
\text { environment }\end{array}$} \\
\hline Dual character $\mathrm{c}$ & velopment: \\
\hline
\end{tabular}

Source: Own study

\section{Systems of agricultural production in Poland}

The development of agriculture is associated with changes in management systems. In absolute terms, we can talk about two forms of agriculture: conventional and organic [Runowski, 1996; Majewski, 2002]. Organic farming produces more good for the environment, and conventional 
agriculture more private goods. The existing comparisons of conventional and organic agriculture in the context of sustainable development focus on organic indicators, often without any evaluation of other performance indicators. To assess the relative sustainability of agricultural systems, one must consider their cumulative effectiveness. On the basis of information held, it can be concluded that both organic and conventional agriculture the production and organic capabilities are not yet fully exploited, which means that in both these systems, there are also reserves of efficiency. One could make more environmental goods and private goods in both of them [Alvensleben, 2000; Majewski, 2008]. Possible efficiencies in organic agriculture is and will be constrained by the strict guidelines established for certified crop farming and animal husbandry. In particular, a total ban on the use of agricultural fertilizers and chemical pesticides may interfere with achieving the improvement of management efficiency and thus reduce their ability to pursue environmental objectives in the long term [Runowski, 2004]. Many studies show that consumers are not willing to accept significantly larger differences in prices between organic and conventional products, and in addition accepted differences in the prices of those products have recently been declining [Bruhn, 2001]. Similarly, taxpayers can in the future (when the scale of the organic production increases) reluctantly refer to acceptance of a high level of financial support to organic farms from budgetary sources. The total abandonment of the use of artificial fertilizers or chemical pesticides is now a strategy that can be accepted by a small (richer or more conscious) part of consumers and taxpayers.

Conventional agriculture, in turn, by reducing the level of previously used external input of and their better, more accurate application, and the use of biological and technology advances can significantly reduce, in relation to the status quo, its adverse impact on the environment, while maintaining high economic efficiency. By applying the principles of good farming practices, reduced production intensity, and precise application of inputs of industrial origin (the better technical and technological solutions), conventional farming can significantly improve its

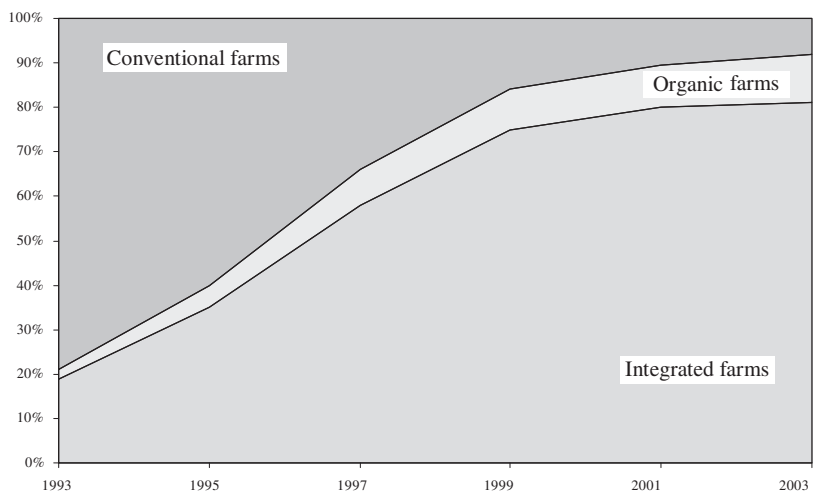

Figure 9. Tendencies of changes in agricultural production systems in Switzerland

Source: Richter T., 2002: Possibilities and barriers for retailing organic products. Research Institute of Organic Agriculture (Switzerland), 2001-2003 own calculations. environmental performance in a short time. This type of farming is called integrated farming. It must be assumed that the future will belong to integrated farming, which occupies an intermediate position between the current conventional agriculture and organic farming [Runowski, 1999; Majewski, 2002]. This trend does not close the possibility of development of organic farming, which is still classified as the market niche. Trends in Poland are likely to be such as in Switzerland (Figure 9).

\section{Conclusions}

Presented considerations entitle to formulate the following conclusions:

1. In the Polish agriculture, there are similar trends as in other European countries, but the level of development in Poland is lower. There is a consistent decline trend in the share of agriculture in gross value added and a drop in the share of employed in agriculture in the total number of employees.

2. In view of the faster pace of growth in labor costs and prices of non-agricultural means of production than the growth in prices of agricultural products, profitability of agricultural production is decreasing.

3. The primary and viable way to bridge the gap between income of employees in agriculture and outside agriculture is the increase of labor productivity in agriculture, which can be achieved due to concentration in the farming sector.

4. The pace of changes in agriculture in order to improve the structure of farms is dependent on the pace of economic development of the country.

5. One way to improve the income situation of farmers may be taking alternative activities. This is possible thanks to the expansion of the functions of agriculture. In addition to the traditional production and social functions, agriculture provides services to the environment and the public.

6. Model of Polish agriculture will have a dual nature in the future. Polarization processes lead to emergence, on the one hand of commercial, on the other hand of subsistence or semi subsistence clusters of farms.

7. Anticipating the changes in agricultural systems in Polish agriculture, it is expected that the importance of integrated agriculture, and partly organic farming, will increase at the expense of conventional farming.

\section{Literature}

1. Agriculture-FADN: F.A.D.N. - FADN PUBLIC DATA. 2008.

2. Alvensleben R., Zur Nachhaltigkeit land- und forstwirtschatlicher Nutzungssysteme - Anmerkungen aus der Sicht eines Agrarökonomen. Agra_Europe 16/2000.

3. Analiza produkcyjno-ekonomicznej sytuacji rolnictwa i gospodarki żywnościowej w latach 1996, 2000, 2005, 2007, 
2008. IERiGŻ - PIB. Warszawa. [Analysis of production and economic situation of agriculture and food economy in 1996, 2000, 2005, 2007, 2008]

4. Bruhn M., Die Nachfrage nach Bioprodukten. Dissertation, Universität Kiel, 2001.

5. Charakterystyka gospodarstw rolnych w 2005 r. GUS. Warszawa 2006. [Characteristics of agricultural farms in 2005]

6. Charakterystyka gospodarstw rolnych w 2007 r. GUS. Warszawa 2008. [Characteristics of agricultural farms in 2007]

7. Józwiak W., Mirkowska Z.: Polskie gospodarstwa rolne w pierwszych latach członkostwa. Zag. Ek. Rolnej 2. Warszawa 2008. [Polish farms in the first years of membership]

8. Majewski E., 2002: Ekonomiczno-organizacyjne uwarunkowania rozwoju Systemu Integrowanej Produkcji Rolniczej (SIPR) w Polsce, Wydawnictwo SGGW, Warszawa [Economic and organizational determinants of the development of the Integrated System of Agricultural Production (SIPR) in Poland]

9. Majewski E., 2008: Trwały rozwój i trwałe rolnictwo - teoria a praktyka gospodarstw rolniczych, Wydawnictwo SGGW, Warszawa [Sustainable development and sustainable agriculture - the theory and practice of agricultural farms, SGGW Publishing]

10. Majewski E., 2008: Historic Landmarks in the Development of Agricultural Land Market in Poland. Apstract, vol.2, Numbers $1-2$.

11. Reisch E.: Rozwój rolnictwa i obszarów wiejskich w Niemczech. Postêpy Nauk Rolniczych PAN.3/2004. Warszawa 2004. [The development of agriculture and rural areas in Germany. Advances in Agricultural Sciences.]

12. Richter T., 2002: Possibilities and barriers for retailing organic products. Research Institute of Organic Agriculture (Switzerland).

13. Rocznik Statystyczny Rolnictwa i Obszarów Wiejskich. GUS. Warszawa 2006. [Statistical Yearbook of Agriculture and Rural Areas]

14. Roczniki Statystyczne GUS. Warszawa 1996-2007. [GUS Statistical Yearbooks]

15. Runowski H., Strategia zrównoważonego rozwoju gospodarstw wyspecjalizowanych w chowie bydła. Wyd. SGGW. Warszawa, 1999. [The strategy for sustainable development of farms specialized in cattle rearing, SGGW Publishing]

16. Runowski H. Gospodarstwo ekologiczne w zrównoważonym rozwoju rolnictwa i obszarów wiejskich. Wieś i Rolnictwo, 3/2004. [Organic farm in the sustainable development of agriculture and rural development. Agriculture and Countryside]
17. Runowski H., Ograniczenia i szanse rolnictwa ekologicznego, Wyd. SGGW. Warszawa 1996. [Limitations and opportunities for organic farming, SGGW Publishing]

18. Runowski H.: Kierunki rozwoju przedsiębiorstw rolniczych w Polsce. Postępy Nauk Rolniczych, nr 3. Warszawa 2004. [Trends in development of agricultural businesses in Poland. Advances of Agricultural Sciences, No. 3]

19. Runowski H.: Postęp biologiczny w rolnictwie. Wyd. SGGW. Warszawa 1997. [Biological progress in agriculture, SGGW Publishing]

20. Runowski H.: Rolnictwo ekologiczne - rozwój czy regres? Roczniki Nauk Rolniczych. T. 96. Zeszyt 4. Warszawa 2009. [Organic farming - development or regression? Yearbooks of Agricultural Sciences]

21. Samuelson P., Nordhaus W., 2004: Ekonomia. PWN. Warszawa. [Economy]

22. Steffen G.: Przedsiębiorstwa rolnicze w Europie Zachodniej. Postępy Nauk Rolniczych PAN 3/2004. Warszawa. [Agricultural enterprises in Western Europe. Advances in Agricultural Sciences]

23. Systematyka i charakterystyka gospodarstw rolnych. Powszechny Spis Rolny 2002. GUS. Warszawa 2003. [Systematics and characteristics of farms. Agricultural Census 2002]

24. Tomczak F.: Od rolnictwa do agrobiznesu. Wydawnictwo Szkoły Głównej Handlowej. Warszawa 2004 [From agriculture to agribusiness. Publishing of the Main School of Economics]

25. Wilkin J.: Wielofunkcyjność rolnictwa i obszarów wiejskich. W „Wyzwania przed obszarami wiejskimi i rolnictwem w perspektywie lat 2014-2020. IRWiR. Warszawa 2008. [Multifunctionality of agriculture and rural development. In "The challenges before rural areas and agriculture in the perspective of 2014 to 2020", IRWIR Publishing]

26. Ziętara W.: Ekonomiczna i społeczna wydajność pracy w różnych typach gospodarstw Rolniczych. Zeszyty Naukowe SGGW. Ekonomika i organizacja gospodarki żywnościowej 40/2000. Wyd. SGGW. Warszawa. [Economic and social performance in various types of agricultural holdings. Scientific Papers of SGGW. Economics and organization of the food economy 40/2000]

27. Ziętara W.: Wydajność pracy w rolnictwie i w różnych typach gospodarstw. Roczniki Naukowe SERiA. Warszawa 2003. [Labor productivity in agriculture and in different types of farms. Yearbooks of SERiA Assoc.]

28. Ziętara W.: Model polskiego rolnictwa - wobec aktualnych wyzwań. Zeszyty Naukowe SGGW, Ekonomika i Organizacja Gospodarki Żywnościowej. Nr 73/2009 [Polish agriculture - to the current challenges. Scientific Papers of SGGW, Economics and Organization of Food Economy] 